\title{
The Need for Research in the Library Field
}

By RICHARD H. LOGSDON

$\mathrm{W}$ HEN I was first asked to open the afternoon session of this meeting with a brief statement on the need for research in the library field, I was told that the assignment would be an easy one; in fact, that the paper was already written. All that was needed was to find the address delivered as the Founder's Day exercises of the School of Library Service at Western Reserve University on June 10, 1930. Somehow neither my memory nor our filing system recorded this good advice. Two hours ago, at the close of the morning session, I was reminded again of this possibility. Over the noon hour $I$ found the address and have here volume one, number one, of the Library Quarterly, the journal which has contributed so much to our literature through the thirty years of its existence. The opening article: "The Place of Research in Library Service"; the author: my predecessor, Dr. C. C. Williamson. Although it was too late to change my notes, I should like to open my remarks by reading a paragraph from page three of this article.

"If the library is to rise to its opportunity as a social institution and educational force it must, it seems to me, begin very soon to attack its problems by a thoroughgoing application of the spirit and methods of research that are being found so effective in every other field. In the natural sciences as well as in the humanistic and social sciences, in the applied sciences, in education, in business and industry, in social service-everywhere except in the library field-extensive programs of research are being carried
Dr. Logsdon is Director of Libraries, Columbia University. This paper was presented at the forth-sixth annual Conference of Eastern College Librarians at Columbia University, November 26, 1960.

out, highly organized and well financed."

I did recall also having made some observations some years ago on the same topic at a meeting of the American Library Association. My assignment then was to summarize six papers presented by a panel dealing with the subject of technical services divisions in libraries. In that summary I said in effect, "If we are to make progress in solving the problems of mounting technical services costs and arrearages which are plaguing so many libraries, we must have continued reexamination of our present procedures and research and experimentation in new methods of accomplishing our objectives. We are doing this now in some of our libraries, but certain types of research and experimentation are difficult of accomplishment by staff members with regular assignments without seriously interfering with necessary day-to-day operations. Perhaps we should take a lesson from industry where a process may be tested in a pilot plant before attempted on a production basis. Better still, if libraries could band together in setting up such a technical services laboratory, if we had as little as fifty thousand dollars per year (then about 2 per cent of our annual technical services operating costs) we might come out at the end of a fiveyear period with new ideas and proce- 
dures capable of saving several times that amount."

This was written twelve years ago. The only changes I would make here today would be to extend the idea from technical services to cover all aspects of librarianship; to double the period to ten years (or better still, indefinitely); and increase the budget by at least tenfold. I would suggest these changes because the environment in which we work today is even more complex than that of 1948. We see evidences of this in almost every issue of every journal dealing with the subject. We are not just imagining the hundred thousand important journals and the thousands of new monographs, documents, and reports appearing every year. On the contrary, we must face day in and day out decisions to order or not to order from among these many thousands of items. At Columbia we have been adding seven hundred to a thousand new journals every year for at least the last dozen years. Few titles can be dropped.

Our faculties are demanding more breadth and depth of collecting; not many years ago our Slavic acquisitions were less than 1 per cent of the total. Today, approximately one book in every fifteen is related to this new area of concern, but we must be concerned with China, too, and India and Pakistan and the whole Middle Eastern area and East Central Europe and now Africa, while at the same time not lessening our representation of Western European and, of course, American materials. This is bringing us new problems in range and diversity of languages, interpolation of bibliographical information into our catalogs, and is even raising havoc with some of our classification systems. We are finding that this specialization in the university is carrying over into the college campus. Young faculty members coming out of our universities want to be able to keep up in their highly specialized fields of research. They may even carry with them opportunities for government contract work, extending local college campus needs well beyond the normal range of the curriculum.

But sheer numbers of items alone is not the problem. If they were like so many reams of typing paper, they would easily be warehoused and distributed on an expendable basis as such uniform stock items are. But in our case each item has its own distinct bibliographical character, as the Cresap, McCormick, and Paget study of the New York Public Library discovered. Research library activities do not lend themselves well to mass-production techniques.

We have good reason to be proud of the record libraries have made in developing good catalogs, but even our best catalogs and indexes seem to be falling far short of the needs of today's researchers. Within the week, the Council of Library Resources release on the Swanson report on searching natural language texts by computer closed on the note that "... even though machines may never enjoy more than partial success in library indexing, a small suspicion might justifiably be entertained that people are even less promising."1 And while we are on the subject of people, let us not forget that we face extremely difficult years ahead in finding people to do the job expected of us. We will need many more librarians with even higher skills than today's jobs require. Our library schools have been turning out something close to seventeen hundred graduates a year. There seem to be at least seven jobs for every graduate according to a recent government release. We have heard for many years the shortage figure of twelve thousand professionally trained librarians. This would take all of the graduates of all of the schools for the next seven years, even if no librarian presently employed left his job. Likewise projections of enrollment

1 "Don R. Swanson, "Searching Natural Language Text by Computer" Science, CXXXII (1960), 1104. 
for our colleges and universities suggest that if we maintain our present ratio of professional librarians to students registered in course, higher education alone could absorb essentially all of the new graduates. If you talk to school librarians, they will give you something of the same picture for their field, and we all know that the public libraries and special libraries are effective competitors with colleges and universities in the employment of new graduates. We must be sure as never before that we are using our manpower to the best advantage.

There are still other characteristics of the environment in which we work which call for renewed emphasis on research and development, but perhaps the greatest need and the greatest opportunity is really to save us from ourselves. Librarians are by nature conservative in their outlook, and no matter what we say, our institutions tend to hold rather sharply to traditional solutions. Perhaps some of these traditional solutions will still prove best in the long run, but they will survive finally only if put to the full test against all competition.

We have created a kind of monster, really, through no fault of ours, save the circumstances. If this monster continues to evolve along its present lines, I fear that it will become a kind of twentiethcentury dinosaur, probably not unlike the brontosaurus. He was a gentle animal, I am told; a leafeater when much of North America was tropical, a perfect place for him, and he grew big and fat and finally weighed forty tons; and then he began to have trouble, first with the toothy meat-eaters, but it was finally the climate that licked him. It changed, and he was too set in his ways to change with it. Unfortunately, he had no Council on Library Resources to bring him around, and fast!

\section{LC Studies Serial Publications}

Scientific and technical serial publications of the world will be the subject of a study to be conducted by the Science and Technology Division of the Library of Congress through support from the National Science Foundation. The study has two objectives: a compilation of a bibliography of sources on scientific and technical serials and, based on a study of these sources, a count of the current serial titles of the world by country and by subject. The bibliography and the census will serve the purpose of bringing under bibliographical control a body of literature essential to librarians in planning acquisitional and informational services.

At the present time, the World List of Scientific Periodicals, published in 1952, is the basis for estimates of the number of scientific serials currently being published throughout the world. The distinction between the present study and such publicaas the List and the 1956-57 Unesco study, Statistics of Newspapers and Other Periodicals, is that the present study will serve as a source both for information concerning the most recently published bibliographies of scientific serials and for a verifiable statistical count based on these sources.

This 1-year study will be under the direction of Charles M. Gottschalk, Head of the Reference Section in the Science and Technology Division. Preliminary results are expected to be published in 6 months.-LC Information Bulletin, XX (July 24, 1961) 436. 